\title{
Examination of the Relationship among Death Anxiety, Spirituality, Religious Orientation and Existential Anxiety*
}

\author{
Merve Halıcı Kurtulan ${ }^{1}$ \\ Social Science University of Ankara
}

\author{
Özlem Karairmak ${ }^{2}$ \\ Bahçeşehir University
}

\begin{abstract}
In this study, the associations among death anxiety, spiritual tendencies, existential anxiety, and religious tendencies were examined. In addition, this study investigated whether these variables changed with respect to demographic characteristics. The study group was composed of 404 university students. Data was collected by administering the personal demographic form, Death Anxiety Scale, Existential Scale, Religious Tendency Scale, and Spirituality Scale. In line with the purpose of the study, the relational screening model and descriptive methods have been used and participants are identified as study groups. Male participants scored significantly higher than female participants. Gender was not found to have an effect on the other variables. Existential anxiety did not differ within groups with respect to having a religious education. Participants who had received a religious education had higher death anxiety and less spiritual tendencies. Motivation for religious tendencies was found to be external. According to the results, death anxiety and existential anxiety are negatively correlated; existential anxiety and spiritual tendencies are positively correlated; and religious tendencies, which have externally motivations, and spiritual tendencies are negatively correlated. Death anxiety, spiritual tendencies, and religious tendencies predict existential anxiety. As suggestions, the number of studies that examine the associations among existential anxiety, religious tendencies, and spiritual tendencies should be increased, and the quality of religious education should be discussed in detail.
\end{abstract}

Keywords

Death anxiety $\bullet$ Existence $\bullet$ Piety $\bullet$ Spirituality

\footnotetext{
* This study is a summary of Merve Halıc Kurtulan's master's thesis and was presented as a verbal notice in the 13th National Psychological Advisory and Guidance Congress on October 8, 2015.

1 Correspondence to: Merve Halıcı Kurtulan, Social Science University of Ankara, Rectorate, Altındağ, Ankara 06050 Turkey. Email: kurtulanmerve@gmail.com

2 Department of Psychological Counseling and Guidance, Faculty of Educational Sciences, Bahçeşehir University, Beşiktaş İstanbul 34353 Turkey. Email: ozlemkarairmak@gmail.com
}

Citation: Halıcı Kurtulan, M., \& Karaırmak, Ö. (2016). Examination of the relationship among death anxiety, spirituality, religious orientation and existential anxiety. Spiritual Psychology and Counseling, 1, 206-217. http://dx.doi.org/10.12738 spc.2016.2.0007 
Death anxiety, which is one of the fundamental topics in mental health, has gained more importance these days, as death is perceived as an abnormal and anxietyprovoking situation and has been defined as the junction point of all worries. Death anxiety, which qualifies as a source of primary anxiety, is considered to be positive anxiety under the existentialist approach, which is seen as the most effective approach on this topic (Yalom, 1999). According to Yalom (1999) the existentialist approach focuses on the conflict that is caused by an individual who is facing the outcomes of existence, and death anxiety is one of the four dimensions that form the content of existential conflict an individual encounters.

Death, which draws humans to seek meaning in life, has become a concept for guiding religious literature as well. Religion is defined as an individual's answer to some of the existential questions within the context of questioning the boundary between life and death, two complementary concepts (Wulff, 2010).

Because of the incompatibility between the positivist scientific approach and religion, the relationship between psychology and psychiatric disturbances has been ignored since the beginning of the 20th century (Larson \& Milano, 1997). Most particularly, religion has been advocated as a justification for neuroticism and mental disorders by prominent figures such as Freud (1927) and Ellis (1988).

Surprisingly, the quantity of research studying the relationships among mental health, religion, and spirituality has recently increased. Studies with religion and spirituality in their titles were investigated in PubMed, and 5,200 related studies were encountered (Bonelli \& Koenig, 2013). In accordance with this study, the prestigious psychiatry and neurology journals that were placed within International Scientific 2010 have been reviewed. Of the reviewed studies, $72 \%$ report positive associations, $18.6 \%$ report negative associations, and only $4.7 \%$ report no association between religion/spirituality and mental health. However, a systematic literature review carried out in 1986 reported that $2.5 \%$ of quantitative studies included a variable related to religion/spirituality (Larson, Pattison, Blazer, Omran, \& Kaplan, 1986). According to the results of a review study that looked at two psychiatry journals between 1978 and 1989, 72\% of studies reported a positive association, 16\% reported a negative association, and $12 \%$ reported no associations with religion/spirituality (Larson et al., 1992).

Apaydın (2010) reviewed international research studies and presented the theoretical relationship between religion/spirituality and mental health from two perspectives: positive and negative. According to Apaydın, studies on the relationship of religiousness with life satisfaction and happiness showed that higher religious beliefs lead to higher life satisfaction and happiness. Studies carried out in Turkey reveal similar mixed 
results. According to his review, having a higher level of religious beliefs was found to be related to more negative emotions in Turkey. This result supports the assumptions and findings of Freud and Ellis. For instance, there is a positive relationship between schizophrenia and religiousness (Watters, 1992). According to another study (Kroll \& Sheehan, 1989) examining the religious beliefs of psychiatric patients, $31 \%$ of patients suffer from depression, 19\% suffer from schizophrenia, 19\% suffer from personality disorders, and $21 \%$ suffer from manic episodes. Irrational beliefs were observed among psychiatric patients, such as being able to communicate directly with God (Pargament, 1997). Severe mental disturbances were positively related to quality of life and spiritual beliefs (Young, 2010). In normal populations, religion and spirituality were found to decrease depression (Wink \& Scott, 2005) and anxiety (Koenig, 2001). Spiritual and religious beliefs decreased stress and facilitated ending addiction (Laudet, Morgen, \& White, 2006). Women tend to have a higher level of spiritual belief than men (WHOQoL SRPB ${ }^{3}$ Group, 2006; Wink \& Dillon, 2002).

There have been a limited number of studies carried out in Turkey. Among Turkish emigrants in Germany, intrinsic religious tendencies are negatively related to anxiety, and extrinsic religious tendencies are positively related to anxiety (Koç, 2013). A high level of religiousness is also associated with negative self-identity, external locus of control, and psychological distress (Dirik \& Günay, 2009). In terms of physical health, people who have poor physical health tend to engage in religious activities (Rippentrop, Altmaier, Chen, Found, \& Keffala, 2005). According to Johnston and Spilka (1991), religious and spiritual factors are accepted as a coping mechanism.

Allport defined religion from two perspectives: intrinsic and extrinsic (Holm, 2004). According to these perspectives, intrinsically religious people are less prejudiced; however; extrinsically religious people are unable to internalize religion, and they interpret religion as an instrumental process (Allport \& Ross, 1967). In Turkey, male university students tend to have extrinsic religious understanding and female university students tend to have intrinsic religious understanding (Mutlu, 2013). In support of this, death anxiety was found to be higher among males than females (Kıraç, 2007).

Although spirituality and religion are used interchangeably, they define different conceptual structures. Religion is an organized system of values and rituals, whereas spirituality is beyond religion; it is possible to have spiritual feelings, but not religious ones (Russinova \& Cash, 2007; Pargament, 1999). Within the context of spirituality, which is a concept above religion, if people ask themselves whether life has meaning

3 World Health Organization- Quality of Life Religiousness, Spirituality, and Personal Beliefs. 
or whether life has another dimension, regardless of one's faith or religiousness, everyone relates to spirituality (Lenoir, 2003).

Although studies have reported a negative relationship between spirituality and death anxiety (Rasmussen \& Johnson, 1994), some studies report no relationship (Wink, 2006). To sum up, there is no consistency in the literature for the associations of death anxiety with religion and spirituality. Because the concepts of spirituality and religion are based on individual experience, it is hard to agree on generally accepted operational definitions (Zinnbauer et al., 1997).

Specifically, a very limited number of studies in Turkey have examined spirituality, religion, and death anxiety. The findings of this study will contribute to the national and international literature. The significance of this study is supported by a Muslim study group. In general, spirituality and religion have been investigated among nonMuslim populations. The general purpose of this study is to determine the roles of death anxiety, spirituality, existential anxiety, and religion in mental health. Firstly, the group differences (gender and informal religious training) were examined over the research variables. Then dual relationships between the research variables were tested. Thirdly, existential anxiety was predicted among two groups: those who had suffered from a significant loss in the last six months and those who had not. In this analysis, the dependent variable was existential anxiety, and the predictor variables were informal religious training (had/did not have), death anxiety, spirituality, and religiousness.

The study's significance lies in identifying the role of death anxiety, spiritual tendencies, existential anxiety, and religious tendencies on mental health. Additionally, the purpose of the study is to investigate the predictor roles of existential anxiety, spiritual tendencies, and religious tendencies on death anxiety.

\section{Method}

\section{Study Group}

The sample consisted of 404 (196 female, 208 male) university students. In order to ensure voluntary participation during data collection on a topic such as death anxiety, which cannot be discussed comfortably in society, a convenient sample was recruited. The age range was 18-32 years old, with a mean age of 22.08. In the study group, the distribution of female participants was $48.5 \%$ and of male participants was $51.5 \%$. Of the sample, $58 \%$ had received religious education outside of school and $41 \%$ had experienced a loss in the previous six months. 


\section{Instruments}

Death Anxiety Scale. The scale developed by Thorson and Powell (1992) was used. The scale has 25 items and is assessed on a 5-point Likert-type scale. Higher scores indicate higher levels of death anxiety. The Turkish adaptation was done by Yildiz and Karaca (2001). Cronbach's Alpha coefficient for the current study is .82.

Spirituality Scale. The scale was developed by Karairmak and Korkut (2009) to measure spirituality, which is a difficult variable to measure both methodologically and conceptually. It consists of 15 questions and is measured using a 5-point Likert-type scale (strongly agree, agree, neither agree nor disagree, don't agree, strongly disagree). The factor structure explains $51 \%$ of the variance. Higher scores on the scale indicate higher levels of spirituality. In the current study, Cronbach's Alpha is .90.

Existential Scale. The original scale, which was developed by Langle and Orgler (2003) in German based on Victor Frankl's Logotherapy, has 46 items and is assessed using a 6-point Likert-type scale. It consists of four dimensions with a Cronbach's Alpha of .93. The Turkish adaptation of the scale was conducted by Karairmak (2009). In the Turkish version, the scale was transformed into six items with one factor. In the current study, Cronbach's Alpha is .82.

Religious Tendency Scale. The Religious Tendency Scale was developed by Allport and Ross (1967) and adapted to Turkish culture by Kayiklik (2000). In the Turkish version, the scale was transformed into 10 items with one factor. In the current study, Cronbach's Alpha is .80.

\section{Procedure and Data Collection}

Voluntary participation is at the core of the current study. The research questions were answered in three steps. In the first phase, the relationships between major variables were examined. In the second phase, whether the research variables had differed based on gender or religious tendency was examined. In the third phase, the predictability of existential anxiety through other variables among individuals who had experienced a loss in the last six months and those who hadn't was examined

\section{Results}

According to Table 1, males have higher levels of death anxiety compared to females, while the other variables do not differ based on gender. 
Table 1

Descriptive Values of Variables Based on Gender

\begin{tabular}{llcccccc}
\hline Gender & & $\mathrm{N}$ & $\bar{X}$ & $S S$ & $S D$ & $f$ & $p$ \\
\hline Death anxiety & Female & 196 & 71.01 & 15.70 & 404 & 42.47 & .000 \\
& Male & 208 & 81.66 & 14.32 & & & \\
Spiritual tendencies & Female & 196 & 28.81 & 10.09 & 404 & 2.99 & .084 \\
& Male & 208 & 30.11 & 12.70 & & & \\
Religious tendencies & Female & 196 & 23.63 & 7.13 & & & \\
& Male & 208 & 23.58 & 8.44 & 404 & 0.767 & .382 \\
Existential anxiety & Female & 196 & 21.22 & 5.96 & & & \\
& Male & 208 & 21.69 & 5.40 & 404 & 0.638 & .425 \\
\hline
\end{tabular}

Group differences based on gender (Wilks Lambda $[\Lambda]=0.89 ; f_{4.397}=11.53$; partial eta square $\left.\left[\eta p^{2}\right]=0.10 ; p=.00\right)$ and the group differences based on religious training $\left(\Lambda=0.845, f_{4.397}=18.25 ; \eta p^{2}=0.15 ; p=.00\right)$ were investigated using MANOVA. According to Table 2, those who had received religious training experienced higher levels of death anxiety compared to those who hadn't $\left(f_{3.400}=12.10 ; p=.00\right.$; $\left.\eta p^{2}=0.03\right)$. The latter group had higher levels of spirituality $\left(f_{3.400}=14.92 ; p=.00\right.$; $\left.\eta p^{2}=0.04\right)$. Individuals who had received religious training tend to have extrinsic religiousness, whilethosereceivednonetend to haveintrinsicreligiousness $\left(f_{3.400}=52.62\right.$; $\left.p=.00 ; \eta p^{2}=0.11\right)$. The levels of existential anxiety did not differ based on whether religious training had been received or not (see Table 2).

Table 2

Descriptive Values of Variables Based on Having Received Religious Training

\begin{tabular}{lccccccc}
\hline Religious training & & $\mathrm{N}$ & $\bar{X}$ & $S S$ & $S D$ & $f$ & $p$ \\
\hline Death anxiety & Yes & 234 & 79.27 & 14.93 & 404 & 12.10 & .001 \\
& No & 170 & 72.67 & 16.46 & & & \\
Spirituality tendency & Yes & 234 & 27.72 & 11.43 & 404 & 14.92 & .00 \\
\multirow{2}{*}{ Religious tendency } & No & 170 & 31.90 & 11.21 & & & \\
& Yes & 234 & 21.35 & 7.28 & 404 & 52.62 & .00 \\
\multirow{2}{*}{ Existential anxiety } & No & 170 & 26.71 & 7.48 & & & \\
& Yes & 234 & 21.63 & 5.59 & 404 & & \\
& No & 170 & 21.24 & 5.81 & & & .564 \\
\hline
\end{tabular}

As can be seen in Table 3, a small, positive, and significant relationship exists between death anxiety and existential anxiety scores. There is a medium, negative, and significant relationship between the spirituality and existential scale scores $(r=-0.354)$. There is a medium, positive, and significant relationship between spirituality and religious tendencies scores $(r=-0.354)$. As spirituality levels increase, so does intrinsic religiousness. A small, negative, and significant relationship exists between the existential and religious tendency scale scores $(r=-0.275)$. As individuals' death anxiety scores decrease, their extrinsic religiousness tendency was found to increase. 
Table 3

Correlation Coefficients between the Study Variables

\begin{tabular}{lcccc}
\hline & Death anxiety & Spirituality & Existential Anxiety & Religious Tendency \\
\hline Death anxiety & 1 & -0.036 & $0.228^{*}$ & -0.018 \\
Spirituality & & & $-0.354^{*}$ & $0.603^{*}$ \\
Existential Anxiety & & & & $-0.275^{*}$ \\
Religious Tendency & & & & 1 \\
\hline
\end{tabular}

$* p<.01$.

In both regression analyses conducted on individuals who had experienced a loss and on those who hadn't, the dependent variable was existential anxiety and the independent variable of the first block was having had religious training. For both groups, religious training was not found to have a predictive role on existential anxiety.

In both analyses, death anxiety, spirituality and religious tendency were entered as the independent variables of the second block, and the model was found to explain approximately $25 \%$ of the observed variance.

When death anxiety, spirituality, and religious tendency were entered as independent variables for those who hadn't experienced a loss, the model explained approximately $16 \%$ of the observed variance.

\section{Discussion}

In this study, the associations among death anxiety, existential anxiety, religiousness, and spirituality were examined. In accordance with the existential approach, results showed that more existential anxiety means less death anxiety. Existential anxiety helps search for meaning in life and plays a coping role in death anxiety; it also increases awareness of the reality of death (Corey, 2008). Yalom (1999) mentioned that existential anxiety helps to give death meaning and also helps to cope with death anxiety. According to Yalom, people who feel the meaning of life are less hopeless than those who do not. According to the results of this study, associations do not exist between either death anxiety and spirituality or death anxiety and religiousness. Similarly, in a study carried out with university students, no relationship existed between intrinsic religious anxiety and death anxiety (Thorson \& Powell, 1989; Rasmussen \& Johnson, 1994). When examining the associations among death anxiety, spirituality, and religiousness, no consistency is found among the findings (Cohen et al., 2005). In this study, no relationship was found between death anxiety and spirituality. Our finding is inconsistent with the study that had reported a negative relationship between 
death anxiety and spirituality in a non-Muslim country (Rasmussen \& Johnson, 1994; Wink, 2006).

In the present study, a significant relationship exists between spirituality and religiousness. For future research, the complex association between spirituality and death anxiety should be examined in different groups. According to the results of the present study, existential anxiety and spirituality are positively related. People with higher levels of spirituality are more anxious existentially. In previous studies, spiritual themes were explained from an existential point of view (Kararmak, 2004; Webb, Toussaint, \& Dula, 2014). When examining the relationship between spirituality and religiousness, people with higher levels of spirituality tend to be more intrinsically religious. Although these two concepts have been used interchangeably in the literature (Kostak, 2007), this finding is consistent with the idea of spirituality being a meta-concept that includes religion (Wax, 2005).

The results of this study have indicated that people with less existential anxiety tend to be more extrinsically religious. Similar to this result, an increase in intrinsic religiousness leads to an increase in meaning of life (Kıraç, 2007). Both the findings from this study and from Kıraç's (2007) support existential elements in the concept of spirituality. Similar to the findings of the present study, Kıraç (2007) reported no relationship had been found between religious tendencies and death anxiety.

The results of this study show that the levels of death anxiety are significantly higher in men than women; on the other hand, no gender difference was found for spirituality or existential anxiety. This result is consistent with Kıraç (2013) and with the findings of Mutlu (2013). This result also indicated that existential anxiety did not change based on the condition of having had informal religious training. On the other hand, death anxiety, spirituality, and religiousness did change based on the condition of having had informal religious training. Those who had received informal religious training had less spiritual tendencies than those who had not. This result supports previous studies that state spirituality is a meta-concept that includes religion (Kostak, 2007). Those who had received informal religious training showed extrinsic religiousness tendencies and higher levels of death anxiety; whereas the ones who didn't receive any informal religious training showed no sign of extrinsic religious tendencies. These results put forward the question of what is the quality of informal religious training and what does it contain. The results of the study show that informal religious training may have a role in increasing the levels of death anxiety. Future studies can examine the associations among religiousness, religious training, and death anxiety from this perspective. 
The regression model explained existential anxiety in two groups: (a) those participants who had had a significant loss in the last six months, and (b) those who had not had a significant loss in the last six months. Death anxiety, spiritual tendencies, and religious tendencies significantly predict existential anxiety in the two different groups. The explained variance in the group of participants who had had a significant loss in the last six months was $25 \%$; however, the explained variance in the other group was $16 \%$. Experiencing a significant loss caused a $9 \%$ increase in variance. This result is compatible with the existential perspective. Facing death facilitates or accelerates the process of giving life meaning. Experiencing a loss can contribute to the questioning of life and creating meaning in it. At the same time, it is possible to interpret that in the face of death, which is an existential crisis, the needs of spirituality and religiousness can increase. Among recently diagnosed cancer patients, spirituality is a protective factor for spiritual relaxation and for finding meaning in their experience (Hounsgaard \& Hvidt, 2013). For future studies, the effect of loss on existential anxiety may be investigated in depth.

\section{Kaynakça/References}

Allan, B., \& Shearer, C. B. (2012). The scale for existential thinking. International Journal of Transpersonal Studies, 31(1), 21-37.

Allport, G. W., \& Ross, J. M. (1967). Personal religious orientation and prejudice. Journal of Personality and Social Psychology, 5, 432-443.

Apaydın, H. (2010). Ruh sağlığı-din ilişkisi araştırmalarına bir bakış. Dinbilimleri Akademik Araştırma Dergisi, 10(2), 59-77.

Bahadır, A. (2002). İnsanın anlam arayışı ve din. İstanbul: İnsan Yayınları.

Baker, D. C. (2003). Studies of inner life: The impact of spirituality on quality of life. Quality of Life Research, 12(Suppl. 1), 51-57.

Bonelli, R. M., \& Koenig, H. G. (2013). Mental disorders, religion and spirituality 1990 to 2010: A systematic evidence-based review. Journal of Religion and Health, 52(2), 657-673. http:// dx.doi.org/10.1007/s10943-013-9691-4

Brown, D. R., Carney, J. S., Parrish, M. S., \& Klem, J. L. (2013). Assessing spirituality: The relationship between spirituality and mental health. Journal of Spirituality in Mental Health, 15(2), 107-122.

Cevizci, A. (2005). Felsefe sözlüğ̈̈. İstanbul: Paradigma Yayınları.

Cohen, A. B., Pierce, J. D., Chambers, J., Meade, R., Gorvine, B. J., \& Koenig, H. G. (2005). Intrinsic and extrinsic religiosity, belief in the afterlife, death anxiety, and life satisfaction in young Catholics and Protestants. Journal of Research in Personality, 39(3), 307-324.

Cohen, S. R., \& Mount, B. M. (2000). Living with cancer: 'Good' days and 'bad' days-What produces them? Can the McGill Quality of Life Questionnaire distinguish between them? Cancer, 89, 1854-1865. 
Corey, G. (2008). Psikolojik danışma kuram ve uygulamaları (T. Ergene, Çev.). Ankara: Mentis Yayınlar1.

Corrington Jr, J. E. (1989). Spirituality and recovery: Relationships between levels of spirituality, contentment and stress during recovery from alcoholism in AA. Alcoholism Treatment Quarterly, 6(3-4), 151-165.

Cramer, A. O., Van Ravenzwaaij, D., Matzke, D., Steingroever, H., Wetzels, R., Grasman, R. P., ... Wagenmakers, E. J. (2016). Hidden multiplicity in exploratory multiway ANOVA: Prevalence and remedies. Psychonomic Bulletin \& Review, 23(2), 640-647.

Daaleman, T. P., \& Kaufman, J. S. (2006). Spirituality and depressive symptoms in primary care outpatients. Southern Medical Journal, 99(12), 1340-1345.

Dirik, G. \& Günay, E. (2009). Dindarlık kontrol odağı ve psikolojik sıkıntılar. Civilacademy Sosyal Bilimler Dergisi, 7, 47-62.

Ellis, A. (1988). Is religiosity pathological? Free Inquiry, 18, 27-32.

Erdoğdu, M. Y. \& Özkan, M. (2007). Farklı dini inanışlardaki bireylerin ölüm kaygıları ile ruhsal belirtiler ve sosyo-demografik değişkenler arasındaki ilişkiler. İnönü Üniversitesi Tip Fakültesi Dergisi, 14(3), 171-179.

Freud, S. (1927). The future of an illusion. Standard Edition, 21, 1-56.

Glas, G. (2007). Anxiety, anxiety disorders, religion and spirituality. Southern Medical Journal, 100, 621-625.

Henrie, J., \& Patrick, J. H. (2014). Religiousness, religious doubt, and death anxiety. International Journal of Aging \& Human Development, 3, 203. http://dx.doi.org/10.2190/AG.78.3.a

Hill, P. C., Pargament, K. I., Hood, R. W., McCullough Jr, M. E., Swyers, J. P., Larson, D. B., ... Zinnbauer, B. J. (2000). Conceptualizing religion and spirituality: Points of commonality, points of departure. Journal for the Theory of Social Behaviour, 30(1), 51-77.

Holm, N. G. (2004). Din psikolojisine giriş (A. Bahadır, Çev.). İstanbul: İnsan Yayınları.

Horozcu, Ü. (2010). Tecrübî araştırmalar 1şığında dindarlık ve maneviyat ile ruhsal ve bedensel sağlık arasındaki ilişki. Milel ve Nihal İnanç, Kültür ve Mitoloji Araştırmaları Dergisi, 7(1), 209-240.

Hounsgaard, L., \& Hvidt, N. C. (2013). Secular, spiritual, and religious existential concerns of women with ovarian cancer during final diagnostics and start of treatment. EvidenceBased Complementary \& Alternative Medicine (Ecam), 2013, 1-11. http://dx.doi. org/10.1155/2013/765419

Johnston, S. C., \& Spilka, B. (1991). Coping with breast cancer: The roles of the clergy and faith. Journal of Religion and Health, 1, 21-33.

Karaırmak, Ö. (2004). Tinsel anlayışın psikolojik danışmadaki rolü. Türk PDR Dergisi, 22, 45-55.

Karaırmak, Ö. (2009, Ekim). Varoluş ölçeğinin kısa formunun psikometrik özellikleri. PDR X. Ulusal Psikolojik Danışma ve Rehberlik Kongresi'nde sunulan bildiri, Adana.

Karaırmak, Ö. \& Korkut Owen, F. (2009, Ekim). Tinsellik ölçeğinin psikometrik özellikleri: Açıklayıcı ve doğrulayıcı faktör analizi. PDR X. Ulusal Psikolojik Danışma ve Rehberlik Kongresi'nde sunulan bildiri, Adana.

Kayıklık, H. (2000). Dini yaşayış biçimleri: Psikolojik temelleri açısından bir değerlendirme (Doktora tezi, Dokuz Eylül Üniversitesi, Sosyal Bilimler Enstitüsü, İzmir). https://tez.yok.gov. tr/UlusalTezMerkezi/ adresinden edinilmiştir. 
Kıraç, F. (2007). Dindarlık eğilimi, varoluşsal kaygı ve psikolojik sağlık (Yüksek lisans tezi, Ankara Üniversitesi, Sosyal Bilimler Enstitüsü, Ankara). https://tez.yok.gov.tr/UlusalTezMerkezi/ adresinden edinilmiştir.

Koç, M. (2013). Dinsel yönelim kaygıyı nasıl etkiler? Almanyalı Müslüman-Türk göçmenler üzerine bir alan araştırması. İstanbul Üniversitesi Illahiyat Fakültesi Dergisi, 29, 39-72.

Koenig, H. (2001). Religion and Medicine II: Religion, mental health, and related behaviors. International Journal of Psychiatry in Medicine, 31(1), 97-109.

Kostak, M. (2007). Hemşirelik bakımının spiritüel boyutu. Fırat Sağlık Hizmetleri Dergisi, 6, 105-115.

Kroll, J., \& Sheehan, W. (1989). Religious beliefs and practices among 52 psychiatric inpatients in Minnesota. American Journal of Psychiatry, 146, 67-72.

Langle, A., \& Orgler, C. (2003). The existence scale. European Psychotherapy, Vienna: Austrian Society for Logotherapy and Existential Analysis, 4(1), 135-151.

Larson, D. B., \& Milano, M. G. (1997). Making the case for spiritual interventions in clinical practice. Mind Body Medicine, 2, 20-30.

Larson, D. B., Pattison, E. M., Blazer, D. G., Omran, A. R., \& Kaplan, B. H. (1986). Systematic analysis of research on religious variables in four major psychiatric journals, 1978-1982. The American Journal of Psychiatry, 143(3), 329-334.

Larson, D. B., Sherrill, K. A., Lyons, J. S., Craigie, F. C, Jr, Thielman, S. B., Greenwold, M. A., ... Larson, S. S. (1992). Associations between dimensions of religious commitment and mental health reported in the American Journal of Psychiatry and Archives of General Psychiatry: 1978-1989. American Journal of Psychiatry, 149(4), 557-559.

Laudet, A. B., Morgen, K., \& White, W. L. (2006). The role of social supports, spirituality, religiousness, life meaning and affiliation with 12-step fellowships in quality of life satisfaction among individuals in recovery from alcohol and drug problems. Alcoholism treatment quarterly, 24(1-2), 33-73.

Lenoir, F. (2003). The metamorphoses of God. Paris, France: Editions Plon.

Mutlu, E. (2013). İ̧̧ güdümlü ve dış güdümlü dindarlık ile ölüm kaygısı arasındaki ilişki: Üniversite ögrrencileriyle bir çalışma (Doktora tezi, İstanbul Arel Üniversitesi, İstanbul). https://tez.yok. gov.tr/UlusalTezMerkezi/ adresinden edinilmiştir.

Pargament, K. I. (1997). The psychology of religion and coping. New York, NY: Guilford Press.

Pargament, K. I. (1999). The psychology of religion and spirituality? Yes and no. The International Journal for the Psychology of Religion, 9(1), 3-16.

Potter, P. A., \& Perry, A. G. (1997). Nursing concepts process and practice (4th ed.). New York, NY: Mosby Year Book Inc.

Rasmussen, C. H., \& Johnson, M. E. (1994). Spirituality and religiosity: Relative relationship to death anxiety. Omega: Journal of Death \& Dying, 29(4), 313-318. http://dx.doi.org/10.2190/ D1M9-3W6J-FY33-G3HQ

Rippentrop, A. E., Altmaier, E. M., Chen, J. J., Found, E. M., \& Keffala, V. J. (2005). The relationship between religion/spirituality and physical health, mental health, and pain in a chronic pain population. Pain, 116(3), 311-321.

Russinova, Z., \& Cash, D. (2007). Personal perspectives about the meaning of religion and spirituality among persons with serious mental illnesses. Psychiatric Rehabilitation Journal, 30(4), 271. 
Salladay, S. A., \& McDonnell, M. M. (1989). Spiritual care, ethical choices, and patient advocacy. Nursing Clinics of North America, 24(2), 543-549.

Thorson, A. J., \& Powell, F. C. (1992). A revised death anxiety scale. Death Studies, 16, 507-521.

Thorson, J. A., \& Powell, F. C. (1989). Death anxiety and religion in an older male sample. Psychological Reports, 64(3), 985-986.

Watters, W. (1992). Deadly doctrine: Health, illness, and Christian God-talk. Buffalo, NY: Prometheus Books.

Wax, S. (2005). Spirituality at work (Goodwork Project Report Series, No.41). Harvard University.

Webb, J. R., Toussaint, L., \& Dula, C. S. (2014). Ritualistic, theistic, and existential spirituality: Initial psychometric qualities of the RITE measure of spirituality. Journal of Religion \& Health, 53(4), 972-985. http://dx.doi.org/10.1007/s10943-013-9697-y

Weems, C. F., Costa, N. M., Dehon, C., \& Berman, S. L. (2004). Paul Tillich's theory of existential anxiety: A preliminary conceptual and empirical examination. Anxiety, Stress \& Coping, 17(4), 383-399.

WHOQoL SRPB Group. (2006). A cross-cultural study of spirituality, religion, and personal beliefs as components of quality of life. Social Science \& Medicine, 62(6), 1486-1497.

Wink, P. (2006). Who is afraid of death? Religiousness, spirituality, and death anxiety in late adulthood. Journal of Religion, Spirituality, \& Aging, 18(2-3), 93-110. http://dx.doi.org/ 10.1300/J496v18n02_08

Wink, P., \& Dillon, M. (2002). Spiritual development across the adult life course: Findings from a longitudinal study. Journal of Adult Development, 9(1), 79-94.

Wink, P., \& Scott, J. (2005). Does religiousness buffer against the fear of death and dying in late adulthood? Findings from a longitudinal study. The Journals of Gerontology, 60, 207-214.

Wulff, D. M. (2010). Psychology of religion. In D. A. Leeming, K. Madden, \& S. Marian (Eds.), Encyclopaedia of psychology and religion (pp. 732-735). New York, NY: Springer.

Yalom, I. (1999). Varoluş̧̧u psikoterapi (Z. İyidoğan Babayiğit, Çev.). İstanbul: Kabalcı Yayınevi.

Yalom, I. (2008). Güneşe bakmak ölümle yüzleşmek (Z. İyidoğan Babayiğit, Çev.). İstanbul: Kabalc1 Yayınevi.

Yıldız, M. \& Karaca, F. (2007). Thorson-Powell ölüm kaygısı ölçeğinin Türkçe çevirisinin normal populasyonda geçerlik ve güvenirlik çalışması. Tabula- Rasa, 1, 43-55.

Young, K. W. (2010). Spirituality and quality of life for Chinese people with severe mental illness. Journal of Religion \& Spirituality in Social Work: Social Thought, 29(1), 1-13.

Zinnbauer, B. J., Pargament, K. I., Cole, B., Rye, M. S., Butter, E. M., Belavich, T. G., ... Kadar, J. L. (1997). Religion and spirituality: Unfuzzying the fuzzy. Journal for the Scientific Study of Religion, 36(4), 549-564. 